\title{
Family firm local involvement and the Local Home Bias phenomenon
}

\author{
Giulia Baschieri, Andrea Carosi, Stefano Mengoli
}

Research has documented that most of retail and institutional investors exhibit a strong preference for stocks issued by nearby listed firms (i.e. Local Home Bias). This phenomenon shapes corporate market value and the cost of funding. In this paper, we investigate whether the Local Home Bias is enhanced in family firms as a consequence of their symbiotic connection with the local community. Using a dataset of 2,951 Italian firm-year observations (1,481 are family firms) over the period 1999-2011, we find that Local Home Bias is not a widespread phenomenon and mainly occurs in founding family firms where the founder serves as CEO. The Local Home Bias is absent in non-family firms or in family firms where the owner has acquired control through a market transaction. Overall, results suggest that locally committed family firms trigger investor preference for local stocks and, in doing so, exploit the dedicated local clientele which shrinks the cost of funding. Ultimately, we argue the social contributions of family firms to the local community could even have opportunistic traits and a non-trivial economic effect.

() 2016 Elsevier Ltd. All rights reserved.

\section{Introduction}

Research highlights that most investors have the tendency to tilt their portfolios towards stocks issued by nearby listed firms (the so-called Local Home Bias, henceforth also LHB). One out of ten companies in a US fund manager's portfolio is chosen because it is located in the same city as the manager (Coval and Moskowitz, 1999) and about twenty percent over optimal is invested, by US retail investors, in firms headquartered within 250 miles (Ivković and Weisbenner, 2005). Literature recognizes the LHB defines segmented markets at the regional level and affects corporate market values and a firm's cost of capital (e.g., Hong et al., 2008; Korniotis and Kumar, 2013). In fact, the LHB implies a portion of local investor wealth will be invested in local equity and the equity-markets are segmented based on investor proximity with the issuing firms: consequently, firms isolated from other listed firms benefit from a larger dedicated clientele of local investors, pushing the market prices up on the available local stocks (e.g., Baschieri et al., 2015; Hong et al., 2008). As a consequence, isolated firms trade at a premium compared to clustered firms. Understanding the root of the LHB, which seems to be partly based on the feeling of familiarity investors have toward local firms (e.g., Huberman, 2001), will therefore have important implications for firm management strategies and entrepreneurial decisions. To date, very few studies have dealt with this issue or provided significant empirical evidence.

We explore a gap in the knowledge and investigate whether the feeling of familiarity among local investors is triggered by the distinctive bond family firms have with their local community, ultimately boosting the preference for stocks issued by nearby (family) firms. There is voluminous research pointing to rational decisional models for stock investment decisions (e.g. Coval and Moskowitz, 2001); yet, recent studies also point to behavioural models which suggest that familiarity is a key factor in explaining these decisions (e.g., Grinblatt and Keloharju, 2001). For instance, previous evidence suggests investors exhibit a bias towards firms that produce easily recognizable products (Frieder and Subrahmanyam, 2005), and towards geographically proximate firms whose chief executives speak the same language as the investor or shares the same cultural background (Grinblatt and Keloharju, 2001). To explain such behaviour, Cao et al. (2011) propose a model where individuals psychologically tend to use a focal choice as benchmark (the status quo) to compare to other possible alternatives. The status quo benchmark is 'familiar, cognitively simple to analyse, salient, and assigned by default' (Cao et al., 2011, 174), which cannot easily be replaced by an alternative due to a psychological fear of change and a fear of the unfamiliar.

We apply this framework to the LHB, and conjecture that local investors have stronger feelings of familiarity toward family firms than toward non-family firms, due to the way family firms establish tighter bonds with local communities and their 
close relationships with stakeholders (see among others Berrone et al., 2010). This increases the willingness of local investors to hold local family firm stocks which become the focal choice or status quo in portfolio decisions. To test this hypothesis we compare the LHB in different kinds of firms, based on the type of owner. Firms are divided into four categories: non-family firms, family firms, founding family firms, and founding family firms where the founder serves as CEO. We expect the effect of the LHB to increase as we move in the analysis from non-family to founder CEO founding family firms, as a consequence of their different capacities to build ties with (and within) the local community (Khanna and Rivkin, 2001).

We posit that the entrepreneur, through her/his actions, can boost and exploit local investor preference for her/his firm's stocks and, in doing so, affects the cost of funding. In fact, we assume the interaction between entrepreneurs and communities is dynamic and as such, the entrepreneur can use her/his networks even to create the business environment (see among others, Miller and Le Breton-Miller, 2005). The networking process should be particularly well enhanced in family firms with respect to non-family firms, due to their stronger ties to the local communities (e.g., Astrachan, 1988; Kahn and Henderson, 1992), especially when the founder serves as CEO (e.g., Fahlenbrach, 2009). To the best of our knowledge, no investigation of this kind has been conducted.

Bridging the research on LHB and family firms, the intent of our paper is at least twofold. On one hand, we test whether the stronger feeling of familiarity toward the local family firms drives the investor preference for local stocks and on the other, we test from a new perspective whether (even large listed) family firms and communities interact, in a way that ultimately shrinks their cost of funding. We expect the LHB and related implications on firm value and entrepreneurial decision making to strengthen in isolated family firms. In addition, we suggest the mixed evidence supporting family firms as best performers in financial markets (e.g., Anderson and Reeb, 2003) is not merely due to the way in which family businesses are defined (Miller et al., 2007) but even to the different emotional and/or economic attachments family firms have to the hosting community, compared to non-family firms. Adding a novel and relevant dimension to family firm research, we believe our study deepens the current understanding on the conflicting findings of family firm performance, and fills a gap in the literature introducing the effect of the local economic development on family firm management strategies and entrepreneurial decisions. The literature already recognizes that - compared to non-family firms - family firms are more prone to active engagement with their stakeholders and preserve their socio-emotional wealth (Cennamo et al., 2012), though we are the first to investigate whether a firm's socio-emotional goal has an economically rational, yet concealed, origin. We suggest the link developed with local communities by a family firm could be instrumental to its economic interests, improving the financial performance via a LHB effect. For the family firm more embedded with its local stakeholders, the consequence would therefore be the reconciliation of the socio-emotional wealth with the economic wealth, two aspects so far kept unrelated by the literature on the topic (e.g., Berrone et al., 2010).

We first present a detailed analysis of the 7,487 shareholders owning at least one share in a typical Italian founding family firm. Conclusive evidence on the existence and the drivers of LHB within the family firm setting, and support for the empirical investigation of the LHB in the family firm context follows. Then, a thirteen year (1999-2011) dataset on 2,951 Italian listed firms (1,481 of which are family firms) is used to estimate the LHB across different types of family firms and non-family firms. The investor preference for local stocks results in isolated firms trading at a premium compared to clustered firms located in regions with the presence of several listed firms. Consistently, we find that the isolated founder-managed family firm has a market value that is on average about 33 percent higher than the similar but clustered founder-managed family firm. Remarkably, we do not find any difference in values when isolated vs. clustered non-family firms are taken: this (lack of) evidence is novel compared to prior findings which do not account for the specific local dynamics related to family (and nonfamily) firms. Overall, our findings show that the preference for local stocks is enhanced by the family firm status, and suggest only locally committed family firms dynamically interact with the hosting community to exploit the local dedicated clientele and shrink their cost of capital.

The remainder of the paper is as follows. Section 2 presents the theoretical development and testable hypothesis. Data collection and research methodology is detailed in Section 3. Section 4 presents the findings, while conclusions and implications for practitioners and researchers are discussed in Section 5.

\section{Family firms and LHB: research focus and theoretical development}

\section{LHB: types of local investors and drivers of their preference for local stocks}

The financial literature recognizes different roots of LHB. On the one hand, LHB stems from information advantages on the local firms: proximity gives investors greater value-relevant information about the local companies, leading to a preference for local firms over the non-local firms (e.g., Coval and Moskowitz, 2001; Ivković and Weisbenner, 2005). On the other hand, behavioural factors also come into play as familiarity is a key element in explaining the preference for local equity: it is associated with a sense of comfort toward what is well known and discomfort with the alien, and adds a non-pecuniary dimension to investment choices (Grinblatt and Keloharju, 2001).

The main drivers underlying the LHB differ according to the type of investor. The preference for local firms affects institutional investors such as mutual funds (e.g., Coval and Moskowitz, 2001), hedge funds managers (e.g., Teo, 2009), investment advisors (e.g., Baik et al., 2010), block acquirers (e.g., Kang and Kim, 2008), and professional traders (e.g., Hau, 2001): in all the cases, the information advantage of the local institutional investors over the local firms is the driver of LHB and the local equity-holdings lead to substantial and positive abnormal returns. However, a growing number of studies highlight that 
retail investors are affected by LHB to an even greater extent. For instance, Ivkovic and Weisbenner (2005) show the average household over-invests in local equity and realizes an additional return of 3.2\% per year from its local holdings, which suggests the LHB also stems from an information advantage for the retail investors. Bodnaruk (2009) and Massa and Simonov (2006) provide further supporting evidence. Yet, Grinblatt and Keloharju (2001) and Huberman (2001) show individuals are more comfortable investing their money in local businesses that are visible and familiar to them. Seasholes and Zhu (2010) find no evidence that individuals earn superior positive returns from their local holdings, which is strongly consistent with a behavioural explanation of LHB. The information and behavioural perspectives of the LHB are bridged in Karlsson and Norden (2007), and Kumar (2009). Karlsson and Norden (2007) show the LHB is correlated with poorly educated males, especially employees in public administration with no experience in risky investments; Kumar (2009) concludes that in periods of market uncertainty, when stocks are harder to value, retail investors have stronger biases and the informed (institutional) investors exhibit a higher intensity of trades due to their attempt and ability to exploit other investors' biases.

In light of the stronger ties and the emotional attachments that family firms have with the community where they are headquartered (e.g., Gómez-Mejía et al., 2007), we posit that local investors perceive the local family firms as more familiar than the non-family firms. As a consequence, we predict the LHB is mainly related to family firm stocks. In line with the literature, the behavioural link with the LHB should be the higher the more retail investors invest in the family firms; on the contrary, the presence of local institutional investors in the firm shareholder base could imply the LHB is also driven by an information advantage that institutional investors - more than retail investors - are able to locally collect and exploit. The detailed analysis of a family firm shareholder base is reported in Section 4.1. Ultimately, the peculiar attachment family firms have with their local community and the multiform categorization of family businesses require testable hypotheses to be developed in the following, dedicated, section.

\section{Family firms and the LHB: testable hypotheses}

Investors are biased towards advertised, visible, and brand name stocks (Frieder and Subrahmanyam, 2005), issued by firms they frequent as customers (Huberman, 2001; Keloharju et al., 2012), and within their two-digit industry of employment (Døskeland and Hvide, 2011). In brief, investors buy what they feel is familiar. Such feelings of familiarity even drive the investor preference for geographic proximate equity (e.g., Grinblatt and Keloharju, 2001) which, in turn, shapes equity prices (e.g., Hong et al., 2008). Cao et al. (2011) explain this behaviour showing individuals evaluate sceptically the choice alternatives that deviate from the status quo benchmark used for their decisions. The status quo is the default and easily processed choice for which investors feel comfortable, competent and familiar. It reflects fear of change and - basic asset-allocation principles notwithstanding - in portfolio decisions this is carried out through an individual's preference for local stocks, which are perceived as most familiar (e.g., Ackert et al., 2005).

As family firms are more embedded in their local community than non-family firms (e.g., Berrone et al., 2010), we posit family firms are perceived as more familiar by local investors, and therefore predict the LHB is mainly related to the stocks they issue. In fact, more than other types of firms, these companies do not focus exclusively on profit maximization. For example, when establishing their headquarters, family firms are sensitive to the proximity of the owner's residence, due to the availability of local recreational and cultural activities and the presence of long-term established networks, etc. (Kahn and Henderson, 1992). In addition, family firms tend to share their prosperity with neighbouring communities (e.g., Graafland, 2002), and rely on surrounding areas as a resource for business operations, including their workforce, clients and suppliers (e.g., Lansberg, 1999). Furthermore, the type of commitment toward economic and non-economic goals is affected by family firm location: family businesses headquartered in rural areas are more focused on social goals such as the protection of the local culture, and less committed to enhancing firm profits (Birley et al. 1999). For example, family firms are more likely to sponsor associations and activities that are valued in the community, such as charities, special events, and local sports teams (Uhlaner, 2006), and address social problems which often exceed the scope of their organizations, such as issues related to poverty or environmental degradation (Westley and Vredenburg, 1991). This type of engagement serves as a way to maintain the long-term relationship between the family and its local stakeholders, who reap social and interpersonal, not merely financial, rewards (Gersick, 2004). The emerging socio-emotional wealth (Gómez-Mejía et al., 2007), that is the stock of affect-related value the family attaches to the business, enhances recognition for generous actions (Schulze et al., 2003) and accumulation of social capital (Arregle et al., 2007). As an example, Berrone et al. (2010) show that family-controlled public firms protect their socio-emotional wealth with better environmental performance than their nonfamily counterparts, particularly at the local level where institutional pressures involving environmental actions have a greater impact. To date, there is no evidence that compliance with these pressures advances the firm's economic interests, although it certainly provides a socio-emotional reward to the family. This type of wealth is naturally accumulated at the local level since local communities define corporate social practices and exercise institutional pressure through environmental groups or citizen lawsuits (e.g., Raines, 2002). Ultimately the firm stands to gain recognition in the community when it complies with the requests, and is sanctioned if it does not (Baker, 1990). Both positive and negative family firm behaviours are easily divulged by the main channels of information transfer between family firms and local stakeholders, the local press, radio and television news (Henriques and Sadorsky, 1996). Ultimately, local news (indirectly) pushes family firms to behave properly to avoid damaging their reputation, meet the family's affective needs and to project a positive public image in the eyes of local investors (e.g. Dyer and Whetten, 2006). In light of the evidence highlighted in the literature, we posit that local investors perceive family firms as more familiar than non-family firms. Therefore, we expect that, when 
facing the non-trivial problem of picking stocks, if investors are attracted by familiarity, then family firms will be favoured. So, our first testable prediction becomes:

\section{H1: family firms show higher LHB than non-family firms}

Using the same logic, we posit that family firms where the founding family remains involved in the ownership and management of the business (founding family firms), are indeed more locally embedded than non-founding family firms, and will be perceived as more familiar by local investors. We therefore predict the LHB is mainly related to the stocks they issue. Ample research emphasizes that family firms are not a homogenous category as the activities aimed at strengthening their local embeddedness will vary based on the weight a family principal places on the different dimensions of socio-emotional wealth preservation (e.g., Berrone et al., 2012; Cennamo et al., 2012). For instance, some family firms have a strong control-dimension and are more likely to devote time, energy, and money to gain support from those stakeholders - such as employees and suppliers - that enlarge the family discretion over the firm's operations, and to put less emphasis on the relationships with external stakeholders such as the local community or local media (Cennamo et al., 2012). We posit non-founding family firms - that did not create or inherit the business - belong to this group, where the economic interest and the control over the operational activities plays a leading role in strategy, at the expense of the other dimensions such as preserving family legacy. On the other hand, other family firms focus more on the preservation of the family dynasty. In these cases, the firm is often founded by the family, and becomes an asset that cannot be easily sold (Cennamo et al., 2012) as it symbolizes the family heritage and tradition (e.g., Tagiuri and Davis, 1992). The socioemotional wealth preservation implies a long-term investment strategy aimed at perpetuating the business so it can be passed on to descendants (Berrone et al., 2010), and the development of trust-based relationships with local partners and suppliers (Oba and Semerciöz, 2005). Accordingly, we postulate founding family firms to belong to this second group of firms. The case of Ford Motor Company provides anecdotal evidence of a highly embedded founding family firm. Although it is one of the world largest, most successful, and most profitable family-controlled firms, Henry Ford maintained the firm headquarters in his small home town on his small farm along the banks of the Rouge River in Dearborn (Michigan) to stay closer to his people. As shown in Block (2010), family business founders and descendants have additional personal ties to the local environment. For instance, founding family firm owners avoid drastically cutting jobs, and show greater identification with the company than non-founding family firm owners since the culture and personal history of the founder inevitably shapes the mission, values, and business practices (Hollander and Elman, 1988). The greater sense of identification translates into greater involvement in the business and the founders are even recognized as stewards of the company (Harris and Ogbonna, 1999). Stewardship accrues in many ways, such as having the founding family name on the business or the likelihood that they perceive their personal satisfaction and public reputation as being tied to the firm and the territory where they live and work. Therefore, while firm-specific factors make family firms more locally embedded than non-family firms, management-specific attributes make founding family firms more locally embedded than non-founding family firms. Ultimately, we posit that local investors perceive the former as more familiar than the latter and therefore, we predict the LHB to be stronger in founding family firms rather than non-founding family firms, which leads to our second testable prediction:

\section{H2: founding family firms show higher LHB than non-founding family firms}

In addition to the dynamics at firm-level and management-level, a third factor strengthens the link between family firms and the surrounding environment: the founder serving as CEO. Consistent with our theoretical framework, we posit founderCEO family firms to be more familiar to local investors, and we expect their stocks to be locally preferred to other local family and non-family firm stocks. The founder-CEO local bond is brilliantly epitomized by Berghoff (2001) who reports the case of the world famous harmonica producer - Hohner AG - a German listed family firm headquartered in Trossigen (Southern Germany). Matthias Hohner, the founder, soon became the most important citizen in town. Without any prior formal education, he even became an adjunct professor at the neighbouring University of Tübingen. According to Berghoff (2001), the strong connection with the local community (e.g., the whole city council was on his pay-roll) was his power. In fact, the founder-CEO has a distinctive influence on family business culture and actions (Athanassiou et al., 2002), invests more in R\&D (Fahlenbrach, 2009) and avoids takeovers (Caprio et al., 2011). In particular, the founder strengthens and creates a more cohesive top management group which ultimately facilitates the strategic planning process and the creation of a shared vision and business culture (Athanassiou et al., 2002). In addition, the founder's vision of the firm is often closely linked to the culture of the local community, and implies continuous involvement in local community affairs to promote the visibility of the family in a positive light (Astrachan, 1988). Literature shows family executives are more likely to prevent losses of socioemotional wealth (Naldi et al., 2013): locally promoting social initiatives, volunteer efforts, and other types of civic leadership (Post, 1993). Overall, the founder is the most locally embedded among the founding family members; as CEO, s/he plays the most significant role in corporate actions that favour the local community thus strengthening the existing firmcommunity bond. Engaging in social initiatives is a way of securing endorsement by the press or the local government and sustains the firm reputation, which is often associated with the family image (e.g., Gomez-Mejia et al., 2011). Therefore, we postulate that the founder serving as CEO further increases the firm's recognition within the hosting community and the 
feeling of familiarity local investors have toward the local family firm. We predict the founder CEO enhances local investor preference for the stocks her/his firm issues. So, our last testable prediction becomes:

\section{H3: founder-CEO founding family firms show higher LHB than other founding family firms}

\section{Data collection and research methodology}

\section{Data}

Firms issuing securities on the Milan Stock Exchange (MSE) over the period 1999-2011 represent the initial sample. The observations i) on common stocks, ii) with ROE within plus and minus one range, and iii) headquartered in Italy are extracted. Because valuation ratios for financial firms are not comparable to valuation ratios for non-financial firms, we excluded financial firms (SIC 6000-6999) throughout the analysis (e.g., Villalonga and Amit, 2006). On the other hand, as both financial and non-financial firms are possible in investors' portfolio (e.g., Flavin, 2004), we kept financial firms to compute variables on the local supply of stocks (e.g., Baschieri et al., 2015; Hong et al., 2008). The final sample includes 2,951 firm-year observations, 1,481 of which are family firms. Data at firm-level are from several sources: i) the databases provided by CONSOB (the Italian regulator) to collect our initial sample and ownership data; ii) Osiris (Bureau Van Dijk database) and Company Annual Reports to collect data on headquarters locations, then converted into latitude and longitude using Google Maps; iii) the electronic archive of Il Sole 240re, which is the most prominent Italian financial newspaper, to collect data on firm press coverage; iv) the yearly investment guides Il Calepino dell'Azionista and Il Taccuino dell'Azionista, for firm age, information on the founders and descendants and the composition of both the top management team and the board of directors; $v$ ) the databases provided by ISTAT, the Italian Institute of Statistics, for information on spatial and wealth distribution of Italian population; vi) Datastream and Worldscope (Thompson Financial) for all other accounting and financial information. In addition, NUTS Codes are used to geographically split Italy (NUTS0) into three nested sub-areas, namely macro-areas (NUTS1), regions (NUTS2), and provinces (NUTS3).

\section{Family firm measurement}

Theory and research typically define family firms as firms where family members maintain ownership stakes and occupy senior management positions (e.g., Anderson and Reeb, 2003; Dyer and Whetten, 2006). Yet, there is lack of consensus on the operational definition of family firms (e.g. Chua et al., 1999). For instance, Minichilli et al. (2010) define family firms as firms where the same family owns more than $50 \%$ of the shares (the threshold is reduced to $30 \%$ for listed companies), and focus on the effect of family management on the firm's performance by classifying family firms using the ratio of the number of family members in the top management team to the total number of top management team members. Anderson and Reeb (2003) use the fractional equity ownership of the founding family and (or) the presence of family members on the Board of Directors. Research clearly shows that control enhancing mechanisms, such as pyramid structures, multiple voting shares, and crossholdings, are deeply embedded in family businesses thus making direct ownership a potentially biased selector for family firms. For instance, Villalonga and Amit (2009) show that in large U.S. corporations, founding families are the only blockholders whose control rights, on average, exceed their cash-flow rights. In order to overcome this issue and to categorize family firms in light of their actual shareholder base, we identify the 'ultimate owner' of the firm through both direct and indirect ownership. Therefore, we followed the trail backwards through the layers of ownership from each direct ownership stake, and define a shareholder as ultimate owner if s/he controls - directly or through an investment vehicle - at least 10 percent of the firm (e.g., Faccio and Lang, 2002; Mengoli et al. 2009). This definition is consistent with international studies on family firm ownership and ensures we only define family firms as those where the majority of votes are, directly or indirectly, held by a family.

Instead of adopting a single definition, in line with Villalonga and Amit (2009) and Pazzaglia et al. (2013) we considered multiple conditions and define family firms with dummy variables at three nested levels of firm family-ness using the firm ownership, management, and control as criteria: (1) Family, a dummy variable which takes the value of 1 if the firm's ultimate owner is a family; (2) Founding Family, a dummy variable which takes the value of 1 for the subsample of Family where the ultimate owner is the founding family and at least one of the founding family members sits on the Board of Directors; (3) Founder CEO, a dummy variable which takes the value of 1 for the subsample of Founding Family where the founder serves as CEO.

The following examples should be useful in clarifying our family firm classifications. Consider the firm, Autogrill Spa, founded in 1947 by the Pavesi family as a chain of roadside stands and restaurants. In 1977, facing financial difficulties, Autogrill Spa was bailed out by the government and merged with two other roadside restaurant operator chains. When Autogrill Spa was privatized in 1995, the Benetton family acquired a controlling stake through the family financial holding, Edizione Srl. Autogrill Spa was listed on the Milan Stock Exchange in 1997, yet the Benetton family maintained a (greater than $10 \%$ ) controlling stake of $50.1 \%$, through the Edizione holding investment vehicle. Thus, we consider Autogrill Spa a family firm, (indirectly) controlled by the Benetton family, which is the Autogrill Spa ultimate owner. Yet, Autogrill Spa is not classified as a founding family firm as the Benetton family did not create or inherit the business (for a similar case see the 
shareholding of Pirelli Spa, reported in Bigelli and Mengoli, 2011). A good example of a founding family firm can be seen in Landi Renzo Spa, a world leader firm in eco-mobility. The company, founded in 1954 by the Landi family, went public in 2007. Through Girefin Spa and Gireimm Srl, two firms owned by the Landi family through the Trust Landi, a Jersey law trust whose beneficiaries are the founder's wife and son, the founding family (indirectly) controls the majority (i.e. 61.86\%) of Landi Renzo Spa. In addition Stefano Landi, a member of the second generation of the founding family, sits on the Board of Directors. As a consequence, we classify Landi Renzo Spa as a founding family firm.

Family firms account for 50\% (1,481 observations) of our sample: 36\% (1,058 observations) are Founding Family, while 13\% (371 observations) are Founder CEO, which is consistent with prior studies showing the majority of Italian listed companies are family firms (e.g., Barontini and Caprio, 2006), and supporting Italy as a quasi-experimental environment for investigations on family capitalism (Aganin and Volpin, 2005; Mengoli et al., 2009).

\section{Other variables}

We use the firm's market-to-book value (MTBV) as dependent variable to measure corporate market value and, to account for the strong positive skewness of the variable $(M T B V$ skewness $=7.83)$, we take its $\operatorname{logarithmic} \operatorname{transformation}(\log (M T B V))^{1}$ (e.g., Hong et al., 2008). As a robustness check, we repeated the analysis with MTBV and results remain unchanged (not reported for brevity). As a proxy for the LHB, we consider the same variable adopted by Hong et al. (2008) who measure the local equity-market conditions through the variable RATIO. RATIO is defined for each firm as the ratio of the sum of the equity book value of listed firms in the region (local supply of stocks) to the disposable income of households in the region (local demand for stocks). Low values of RATIO reveal isolated firms or a low concentration of listed firms around the firm headquarters, and a high unsatisfied local potential demand for local stocks. On the other hand, a high value of RATIO defines clustered firms and no (or little) unsatisfied local demand for stocks issued by nearby firms. Therefore, the LHB implies a negative relation between RATIO and $\log (M T B V)$, meaning that isolated firms trade at premium. Formally, considering the geographic region $j$ where $i$ listed firms and $k$ households are located at year $t$, we define RATIO as

$$
\text { RATIO }_{\mathrm{j}, \mathrm{t}}=\frac{\sum_{\mathrm{i}} \text { Book Value }_{\mathrm{i}, \mathrm{j}, \mathrm{t}}}{\sum_{\mathrm{k}} \text { Disposable Income }_{\mathrm{k}, \mathrm{j}, \mathrm{t}}}
$$

To identify the Italian regions we refer to NUTS2 subdivision. ${ }^{2}$ To exclude any artificial relationship between $R A T I O$ and $M T B V$, in regression analysis, we calculate $R A T I O$ both excluding the Book Value of the corresponding firm from the numerator and dropping financial income from Disposable Income.

In the multivariate analysis, results are controlled through a rich set of control variables that can affect firm market performance. We use: the ownership stake held by the owner (Own); equity profitability (ROE); firm age (Log(Age)); firm size $(\log ($ Size $))$; firm press coverage $(\log (1+$ Press Coverage $))$, based on the number of Il Sole 24Ore articles that mention the firm name within the previous year; and the firm inclusion in the primary Italian equity market index (FTSE). Consistent with previous findings (e.g., Fang and Peress, 2009), Own, ROE, Press Coverage and FTSE are expected to be positively related to $\log (M T B V)$, while Age and Size are expected to have a negative effect. We also include year dummies to address temporal trends and exchange segment listing dummies to account for market microstructure. Moreover, to deal with any time-series and cross-sectional dependence that may characterize panel data sets, we run the analysis clustering standard errors at firmand year-level, as in Petersen (2009).

\section{Regression approach}

We investigate the effect of RATIO on $\log (M T B V)$ in (1) Family, (2) Founding Family, and (3) Founder CEO. We expect a negative relation between $\log (M T B V)$ and $R A T I O$, and according to testable hypotheses we expect the effect of $R A T I O$ on $\log (M T B V)$ is stronger shifting from Non Family to Founder CEO. Operationally, as baseline, we first estimate the effect of RATIO on $\log (M T B V)$. Then, we add the interaction term $R A T I O \times$ Family to the model to assess the additive effect of RATIO on $\log (M T B V)$ due to the family firm status, as well as the stand-alone dummy Family as control. The coefficient of the interaction term represents the statistical test of the hypothesis H1. In the same vein, we further add the Founding Family dummy and the interaction term RATIO $\times$ Founding Family to test the hypothesis $\mathrm{H} 2$, and the Founder CEO dummy with $R A T I O \times$ Founder CEO to test H3.

\footnotetext{
${ }^{1}$ The skewness of $\log (\mathrm{MTBV})$ is equal to 0.19 , that is decidedly closer to the target value of zero expected for a normal distribution compared to the 7.83 skewness measured for the MTBV variable.

2 There are three functional pieces of evidence supporting this choice. First of all, the average (median) surface area of each Italian region corresponds to $4.97 \%(5.79 \%)$ of Italy, which is approximately the same critical area (5.28\% of the U.S. surface) that Ivković and Weisbenner (2005) find effective in distinguishing local from non-local investors. Secondly, the regional sub-division most closely matches the Italian historical pre-unification segmentation. Therefore, the segmentation at region-level is more likely to catch the post-unification persistent cultural segmentation thus emphasizing the behavioural dynamics leading LHB (Grinblatt and Keloharju, 2001). Finally, referring to Italy, Guiso et al. (2004) show proof of the positive effects of regional financial development on the economic success of the same geographical area. Hence, the regional sub-division also allows us to control for local dynamics on the financial side.
} 
Table 1

Founding family firm and type of local investors: the Landi Renzo Spa case-study. Panel A depicts the ownership structure of Landi Renzo Spa. Panel B i) categorises the Italian shareholders of Landi Renzo Spa by location, as within (In-Province) and outside (Out-of-Province) the province of Landi Renzo Spa headquarters; ii) reports the probability of holding at least one share of Landi Renzo Spa based on investor location, and iii) tests whether this probability is higher for an In-Province investor than for an Out-of-Province investor. t-statistics are reported in parenthesis. ${ }^{* * *},{ }^{* *}$, and * indicate statistical significance at the $1 \%, 5 \%$, and $10 \%$ levels.

\begin{tabular}{|c|c|c|c|c|c|}
\hline \multicolumn{6}{|c|}{ Panel A - Landi ownership structure as registered at July 31, 2009} \\
\hline & Investor type & \multicolumn{2}{|l|}{ Shareholder\# } & Stake \% & Stake\# (shares) \\
\hline \multirow[t]{2}{*}{ Family } & \multirow{2}{*}{$\begin{array}{l}\text { Landi Stefano } \\
\text { Domenichini Giovanna }\end{array}$} & \multirow{2}{*}{\multicolumn{2}{|c|}{$\begin{array}{l}\text { CEO, Board VP \& founder son } \\
\text { Board Chairman \& Founder Wife }\end{array}$}} & $30.93 \%$ & $33,247,565$ \\
\hline & & & & $30.93 \%$ & $33,247,565$ \\
\hline \multirow[t]{3}{*}{ Retail } & Italian & \multicolumn{2}{|c|}{7219} & $9.70 \%$ & $10,422,387$ \\
\hline & Foreign & \multicolumn{2}{|l|}{6} & $0.01 \%$ & 7306 \\
\hline & All & \multicolumn{2}{|l|}{7225} & $9.71 \%$ & $10,429,693$ \\
\hline \multirow[t]{3}{*}{ Institutional } & Italian & \multicolumn{2}{|l|}{62} & $6.38 \%$ & $6,853,955$ \\
\hline & Foreign & \multicolumn{2}{|l|}{198} & $22.05 \%$ & $23,703,363$ \\
\hline & All & \multicolumn{2}{|l|}{260} & $28.43 \%$ & $30,557,318$ \\
\hline \multicolumn{2}{|l|}{ All } & \multicolumn{2}{|l|}{7487} & $100 \%$ & $107,482,141$ \\
\hline \multicolumn{6}{|c|}{ Panel B - Landi ownership structure \& shareholders location } \\
\hline & Shareholder\# & Potential investor\# & \multicolumn{2}{|c|}{ Prob (Landi investor) } & $\Delta$ Prob (Landi investor) \\
\hline Retail & 7219 & $60,045,068$ & \multicolumn{2}{|c|}{$0.01 \%$} & $0.17 \%^{* * *}(9.258)$ \\
\hline In-Province & 915 & 519,458 & \multicolumn{2}{|l|}{$0.18 \%$} & \\
\hline Out-of-Province & 6304 & $59,525,610$ & \multicolumn{2}{|l|}{$0.01 \%$} & \\
\hline Institutional & 62 & 90,498 & \multicolumn{2}{|l|}{$0.07 \%$} & $0.48 \% * * *(5.989)$ \\
\hline In-Province & 4 & 733 & \multicolumn{2}{|l|}{$0.55 \%$} & \\
\hline Out-of-Province & 58 & 89,765 & \multicolumn{2}{|l|}{$0.06 \%$} & \\
\hline All & 7281 & $60,137,235$ & \multicolumn{2}{|l|}{$0.01 \%$} & $0.17 \% * * *(8.374)$ \\
\hline In-Province & 919 & 520,191 & \multicolumn{2}{|l|}{$0.18 \%$} & \\
\hline Out-of-Province & 6362 & $59,617,044$ & $0.01 \%$ & & \\
\hline
\end{tabular}

\section{Findings}

\section{LHB and type of local investors: a case-study}

To gain deeper understanding of individual investor behaviour, we collected information on all the registered shareholders (at July 31, 2009) of a typical Italian family firm, Landi Renzo Spa. For each of the 7,487 shareholders (representing the entire firm shareholder base), we collected the following information: name, type of investor (i.e., family firm member, institutional, or retail), province of residence (firm headquarters for the institutional investors), and the number of shares and stake held. These data provide a unique clinical insight into the characteristics of the actual investors holding shares in family firms and are used to explore the LHB effect in a specific context. We benefit from these data thanks to the extremely valuable support of management at Landi Renzo Spa.

Table 1 provides a description of the 7,487 registered shareholders of Landi Renzo Spa, headquartered in the Reggio Emilia province (North East Italy). Panel A depicts the Landi Renzo Spa ownership structure distinguishing the members of the founding family (Family), from the retail and institutional investors (Retail vs. Institutional), located either in Italy or abroad (Italian vs. Foreign). Panel B analyses the Italian shareholders located within and outside the Landi Renzo Spa province (InProvince vs. Out-of-Province), and tests whether the probability of holding at least one share of Landi Renzo Spa is higher for an investor In-Province than Out-of-Province (i.e., $\Delta$ Prob(Landi Investor) $>0$ ). To the extent that the difference in the probability of being a Landi Renzo Spa shareholder In-Province and Out-of-Province is positive and statically significant, evidence of LHB is provided.

Panel A shows that ownership by the family firm founder's wife (Giovanna Domenichini) and son (Stefano Landi) is over $50 \%$, with an aggregate stake equal to $61.86 \%$ of firm equity ${ }^{3}$. The Italian retail investors account for 7,219 of the 7,485 ( $96.45 \%$ ) shareholders not in the family, with a total stake of $9.70 \%$. Apart from the family members, the largest aggregate stake is held in foreign institutional investors' portfolios, with 198 investors owning $22.05 \%$ of the firm equity. Overall, $77.94 \%$ of the firm is held in Italy.

Panel B shows that 915 of the 7,219 (12.68\%) Italian retail shareholders of Landi Renzo Spa reside in the same province as the firm, while the total number of individuals who reside in this province is 519,458 , representing less than $1 \%(0.87 \%$ ) of the Italian population $(60,045,068$ individuals). The implication is that the probability that a retail investor will hold shares in Landi Renzo Spa - computed as the ratio of the number of the actual retail shareholders (Shareholder \#) to the resident population (Potential Investor \#) - is considerably higher In-Province, equalling $0.18 \%$, than Out-of-Province, where it is only $0.01 \%$. The difference in probabilities is equal to $0.17 \%$, statistically significant at $1 \%$ level. In economic terms, these figures

\footnotetext{
3 The family of the founder owns 61.86\% of Landi Renzo Spa indirectly, via Girefin Spa and Gireimm Srl; Girefin Spa and Gireimm Srl are owned by the Trust Landi, a Jersey law trust whose beneficiaries are Stefano Landi and Giovanna Domenichini: an equal indirect stake for each of the Landi family members has been assumed.
} 

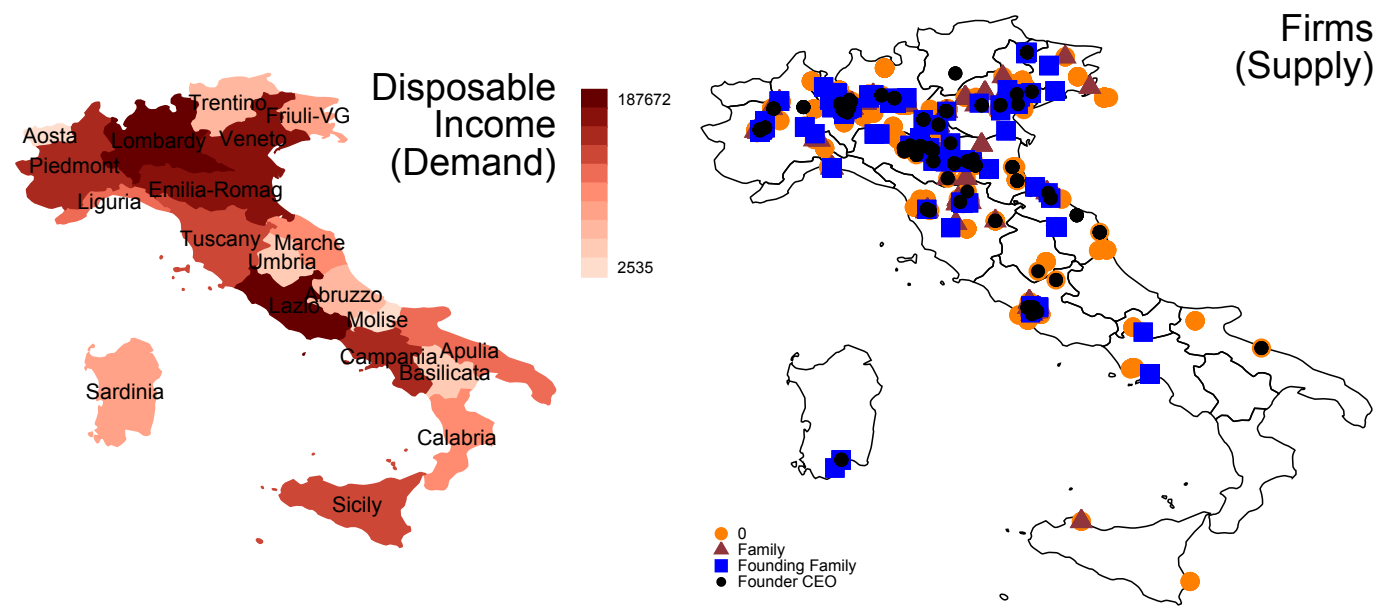

Figure 1. The geography of family firms and investors' disposable income. The left-hand picture reports the yearly average value over the period 1999-2011 of Disposable Income (in million euros) represented by the shading of the corresponding region (NUTS2). The right-hand picture reports the location of each firm's headquarters, distinguishing Non Family (orange-circular data-point), Family (brown-triangular data-point), Founding Family (blue-square data-point) and Founder CEO (black-circular data-point).

imply that within the Landi Renzo Spa province 18 people out of 1,000 are shareholders in the local family firm; outside the province, this tendency decreases to less than 1 person out of 1,000. Results do not significantly differ when institutional investors are considered. In fact 4 out of 62 (6.45\%) institutional shareholders are headquartered in the same province as Landi Renzo Spa, and the total number of Institutional In-Province shareholders is 733 , or $0.81 \%$ of the 90,498 Italian institutional investors. This means that an In-Province institutional investor has a probability of holding Landi Renzo Spa shares equal to $0.55 \%$, with a difference that is $0.48 \%$ higher (and statistically significant at $1 \%$ level) than the probability associated with an Out-of-Province institutional investor, equalling a mere $0.06 \%$. This pattern is unchanged when the entire universe of shareholders is considered: the significantly higher probability of being a shareholder of Landi Renzo Spa for In-Province investors provides conclusive evidence of the LHB in the Italian family firm setting, and supports an empirical investigation to test the effects of the phenomenon in this specific context. Finally, the fact that almost all (96.45\%) the shareholders not in the founding family are retail investors - of which $12.68 \%$ are In-Province - suggests the preference for local has a behavioural root, as it mainly affects local retail investors. Ultimately, the small stake (only $6.38 \%$ of firm equity) held by Italian institutional investors, and the fact that only 4 out of 62 is headquartered In-Province, suggests that the phenomenon is not driven by large institutional investors, such as local banks or other intermediaries, in an attempt to exploit an information advantage due to proximity ${ }^{4}$.

\section{Local market conditions and family firm characteristics}

Figure 1 and Table 2 depict the firm sample and summary statistics. The left-side picture of Figure 1 shows the spatial pattern of Italian investor Disposable Income, while the right-hand picture plots the headquarters of the sampled firms, distinguishing Non Family, Family, Founding Family and Founder CEO firms. Table 2 provides summary statistics on the whole sample (NUTS0), and the subsamples split by macro-areas (NUTS1) and regions (NUTS2).

Figure 1 points out that the Italian equity-market is characterized by a significant spatial clustering of listed firms, together with widespread investor wealth. Such a mismatch implies the presence of strong imbalances between the local demand and the local supply for stocks. Table 2 provides a numerical quantification of these figures. More than $75 \%$ (2,287 observations) of Italian listed firms are located in the northern part of the country (56\%, or 1,655 observations, of the firms are in the NorthWest and 21\%, or 632 observations, in the North-East). The Family representation is consistent in all macro-areas but the South where Family is only about 28\% (14 observations). For Founding Family and Founder CEO firms, we report similar patterns. In line with previous findings, the northern areas of the country have higher than sample average values of RATIO, while the southern areas and the Islands are lower than sample average. ${ }^{5}$

\footnotetext{
${ }^{4}$ For robustness, we re-run the analyses taking the population with age equal or larger than 18 for Retail, and the number of all firms for Institutional. In all cases, results (not reported) remain unchanged. In addition, in line with the regional perspective of the multivariate analysis, we re-run all the statistics also considering In-Region and Out-of-Region investors. Results (not reported) are entirely unchanged.

${ }^{5}$ Looking at the regional distribution, the highest values of RATIO are in Lazio (C), averaging 0.886 while Piedmont comes second with 0.693 . This arises because of the clustering of State-Owned Enterprises (SOEs) around the Italian capital, Rome (Lazio). Indeed, SOEs account for 5.5\% (162 observations) of our sample, of which an impressive 32.3\% (52 observations) are in Rome. At the other end of the spectrum, not considering regions with no listed firms where RATIO obviously equals zero, we find Umbria (C), Abruzzo (S), Trentino Alto Adige (NE) and Sicily (I) averaging 0.001. The region of Apulia (S) follows with 0.002 .
} 
Table 2

Family firms and the local supply and demand for stocks. Data are ranked upon RATIO. Book Value and Disposable Income are in million euros. Book Value, Disposable Income, and RATIO are the average yearly values on 1999-2011.

\begin{tabular}{|c|c|c|c|c|c|c|c|}
\hline & Obs (\%) & Family (\%) & Founding (\%) & Founder CEO (\%) & Book value (\%) & Disposable income (\%) & RATIO \\
\hline Italy (NUTS0) & $2951(100)$ & $1481(50)$ & $1058(36)$ & 371 (13) & $318,336(100)$ & $969,925(100)$ & 0.483 \\
\hline \multicolumn{8}{|l|}{ Macro-area (NUTS1) } \\
\hline Centre $(\mathrm{C})$ & $591(20)$ & $299(51)$ & $200(34)$ & $95(16)$ & $110,371(35)$ & $202,772(21)$ & 0.589 \\
\hline North-West (NW) & $1655(56)$ & $792(48)$ & $544(33)$ & $137(8)$ & $171,700(54)$ & $303,102(31)$ & 0.582 \\
\hline North-East (NE) & $632(21)$ & $360(57)$ & $288(46)$ & $131(21)$ & $34,690(11)$ & $211,223(22)$ & 0.163 \\
\hline Islands (I) & $23(1)$ & $16(70)$ & $12(52)$ & $5(22)$ & $1069(0)$ & $81,602(8)$ & 0.007 \\
\hline South (S) & $50(2)$ & $14(28)$ & $14(28)$ & $3(6)$ & $504(0)$ & $171,226(18)$ & 0.004 \\
\hline \multicolumn{8}{|l|}{ Region (NUTS2) } \\
\hline Lazio $(\mathrm{C})$ & $356(12)$ & $179(50)$ & $136(38)$ & $60(17)$ & $96,131(30)$ & $96,111(10)$ & 0.886 \\
\hline Piedmont (NW) & $359(12)$ & $174(48)$ & $141(39)$ & $34(9)$ & $57,078(18)$ & $82,672(9)$ & 0.693 \\
\hline Lombardy (NW) & $1225(42)$ & $600(49)$ & $393(32)$ & $103(8)$ & $99,357(31)$ & $187,672(19)$ & 0.554 \\
\hline Liguria (NW) & $71(2)$ & $18(25)$ & $10(14)$ & $0(0)$ & $15,261(5)$ & $30,223(3)$ & 0.522 \\
\hline Friuli-VG (NE) & $66(2)$ & $8(12)$ & $5(8)$ & $0(0)$ & $11,482(4)$ & $22,288(2)$ & 0.413 \\
\hline Tuscany (C) & $170(6)$ & $81(48)$ & $25(15)$ & $11(6)$ & $12,954(4)$ & $66,284(7)$ & 0.170 \\
\hline Emilia-Romagna (NE) & $359(12)$ & $225(63)$ & $187(52)$ & $94(26)$ & $12,410(4)$ & $85,105(9)$ & 0.146 \\
\hline Veneto (NE) & $204(7)$ & $124(61)$ & $93(46)$ & $34(17)$ & $10,775(3)$ & $84,741(9)$ & 0.114 \\
\hline Marche (C) & $52(2)$ & $38(73)$ & $38(73)$ & $23(44)$ & $1168(0)$ & $25,850(3)$ & 0.037 \\
\hline Sardinia (I) & $14(0)$ & $12(86)$ & $12(86)$ & $5(36)$ & $986(0)$ & $22,116(2)$ & 0.012 \\
\hline Campania (S) & $28(1)$ & $10(36)$ & $10(36)$ & $0(0)$ & $268(0)$ & $67,768(7)$ & 0.005 \\
\hline Molise (S) & $11(0)$ & $1(9)$ & $1(9)$ & $0(0)$ & $155(0)$ & $4285(0)$ & 0.004 \\
\hline Apulia (S) & $9(0)$ & $3(33)$ & $3(33)$ & $3(33)$ & $232(0)$ & $49,242(5)$ & 0.002 \\
\hline Sicily (I) & $9(0)$ & $4(44)$ & $0(0)$ & $0(0)$ & $152(0)$ & $59,486(6)$ & 0.001 \\
\hline Trentino AA (NE) & $3(0)$ & $3(100)$ & $3(100)$ & $3(100)$ & $88(0)$ & $19,089(2)$ & 0.001 \\
\hline Abruzzo $(S)$ & $2(0)$ & $0(0)$ & $0(0)$ & $0(0)$ & $25(0)$ & $18,539(2)$ & 0.001 \\
\hline Umbria (C) & $13(0)$ & $1(8)$ & $1(8)$ & $1(8)$ & $119(0)$ & $14,527(1)$ & 0.001 \\
\hline Calabria (S) & $0(0)$ & $0(0)$ & $0(0)$ & $0(0)$ & $0(0)$ & $23,979(2)$ & 0.000 \\
\hline Basilicata $(\mathrm{S})$ & $0(0)$ & $0(0)$ & $0(0)$ & $0(0)$ & $0(0)$ & $7413(1)$ & 0.000 \\
\hline Aosta Valley (NW) & $0(0)$ & $0(0)$ & $0(0)$ & $0(0)$ & $0(0)$ & $2535(0)$ & 0.000 \\
\hline
\end{tabular}

Table 3 compares mean and median of the variables involved in the analysis for the subsamples Family vs. Non Family (Panel A), Founding Family vs. Non Founding Family (Panel B), and Founder CEO vs. Non Founder CEO (Panel C).

As far as the dependent variable (MTBV) is concerned, the investigated subsamples are not significantly different among each other, at least using a parametric t-test ${ }^{6}$. A similar behaviour is detected for the main endogenous variable $R A T I O$, suggesting the geographical distribution of the investigated sample is not affected by firm ownership, management and control. Otherwise, Own, Age, Size, Press Coverage, and FTSE significantly differ among the subsamples. For instance, the higher the family involvement in the firm, the higher the average ownership stake held by the family, equalling $47 \%$ for Family, 50\% for Founding Family, and 53\% for Founder CEO firms. Similar patterns can also be detected for the remaining variables. In conclusion, the family firm status discriminates companies when most of the main firm characteristics are considered; yet, it does not imply a difference related to the geographic, environmental conditions. In other words, non-family and the different types of family firms, on average, are not significantly different from each other at least as far their geographic distribution is concerned: for instance, family firms and non-family firms are not clustered in distinct areas of the country, where environmental-specific features (e.g. the economic development of the area) can discordantly affect their performance. Yet, the evidence that most of the considered variables diverge among the subsamples implies that we cannot limit the empirical testing to the univariate analysis, and that we need to control for their effect on MTBV with a multivariate approach.

\section{Family firm value within regionally segmented market}

Table 4 reports the results of the effect of RATIO on $\log (M T B V)$ based on family firm status. Model (1) is our baseline specification while Models (2), (3), and (4) test whether the LHB increases in Family, Founding Family, and Founder CEO firms respectively.

Model (1) shows that in our sample the LHB is in place, consistent with findings by Hong et al. (2008) for the US market. In fact, the effect of RATIO on MTBV is negative and statistically significant as expected $(\beta=-0.113, \mathrm{p}<0.01)$, meaning that more isolated listed firms trade at a premium thanks to the local investors dedicated clientele. Yet, Model (2) highlights that the LHB does not indiscriminately exist in all firms and is only found in family firms. In fact, once Family firms are analysed, the RATIO parameter loses its statistical power $(\beta=-0.011, \mathrm{p}>0.10)$, which shifts into the significance of the coefficient of RATIO $\times$ Family, negative and significant as expected $(\beta=-0.178, \mathrm{p}<0.05)$. H1 is, therefore, supported. When we consider

\footnotetext{
${ }^{6}$ For all the investigated samples, MTBV mean values are higher than median values. Consistent with the statistic reported in Section 3.3, this evidence further proves MTBV skewness and supports the use of the logarithmic version of the variable in the multivariate analysis.
} 
Table 3

Descriptive statistics and univariate analysis by family firm. The mean and median univariate comparisons of the main variables involved in the multivariate analysis are reported for the subsamples of Family and Non Family (Panel A), Founding Family and Non Founding Family (Panel B), and Founder CEO and Non Founder CEO (Panel C). ${ }^{* * *},{ }^{* *}$, and * indicate statistical significance at the $1 \%, 5 \%$, and $10 \%$ levels.

\begin{tabular}{|c|c|c|c|c|c|c|}
\hline & $\mu$ & Median & $\mu$ & Median & $|\mathrm{t}|$ & $\left|\chi^{2}\right|$ \\
\hline Panel A & \multicolumn{2}{|c|}{ Family $(\mathrm{N}=1481)$} & \multicolumn{4}{|c|}{ Non family $(\mathrm{N}=1470)$} \\
\hline MTBV & 2.37 & 1.73 & 2.33 & 1.73 & 0.64 & 1.57 \\
\hline RATIO & 0.33 & 0.32 & 0.33 & 0.32 & 0.41 & 0.08 \\
\hline Own & 0.47 & 0.52 & 0.44 & 0.50 & $10.42^{* * *}$ & $104.21^{* * *}$ \\
\hline ROE & 0.05 & 0.07 & 0.04 & 0.06 & 0.41 & 1.86 \\
\hline Age & 23 & 24 & 26 & 32 & $6.14^{* * *}$ & $54.62^{* * *}$ \\
\hline Size & $2,211,313$ & 322,173 & $4,505,380$ & 453,374 & $9.77^{* * *}$ & $272.75^{* * *}$ \\
\hline Press Coverage & 12.55 & 11.94 & 16.78 & 15.03 & $10.32^{* * *}$ & $88.57^{* * *}$ \\
\hline FTSE & 0.06 & 0.00 & 0.16 & 0.00 & $11.07^{* * *}$ & $39.66^{* * *}$ \\
\hline Panel B & \multicolumn{2}{|c|}{ Founding Family $(\mathrm{N}=1058)$} & \multicolumn{4}{|c|}{ Non Founding Family $(\mathrm{N}=423)$} \\
\hline MTBV & 2.30 & 1.73 & 2.60 & 1.71 & 0.53 & 0.09 \\
\hline RATIO & 0.33 & 0.32 & 0.32 & 0.32 & $1.78^{*}$ & 2.35 \\
\hline Own & 0.50 & 0.54 & 0.39 & 0.43 & $12.56^{* * *}$ & $148.48^{* * *}$ \\
\hline ROE & 0.05 & 0.07 & 0.07 & 0.08 & 1.34 & 0.80 \\
\hline Age & 24 & 24 & 21 & 22 & $5.83^{* * *}$ & $47.92^{* * *}$ \\
\hline Size & $1,882,669$ & 328,945 & $3,246,217$ & 287,610 & $7.40^{* * *}$ & $161.09^{* * *}$ \\
\hline Press Coverage & 12.81 & 11.94 & 11.82 & 11.02 & $7.00^{* * *}$ & $36.29^{* * *}$ \\
\hline FTSE & 0.05 & 0.00 & 0.10 & 0.00 & $9.04^{* * *}$ & $26.94^{* * *}$ \\
\hline Panel C & \multicolumn{2}{|c|}{ Founder CEO $(\mathrm{N}=371)$} & \multicolumn{4}{|c|}{ Non Founder CEO $(\mathrm{N}=687)$} \\
\hline MTBV & 2.55 & 1.89 & 2.16 & 1.65 & 1.30 & $4.95^{* *}$ \\
\hline RATIO & 0.33 & 0.32 & 0.33 & 0.32 & 0.79 & 0.32 \\
\hline Own & 0.53 & 0.57 & 0.49 & 0.53 & $9.04^{* * *}$ & $81.61^{* * *}$ \\
\hline ROE & 0.02 & 0.05 & 0.06 & 0.08 & $3.15^{* * *}$ & $18.47^{* * *}$ \\
\hline Age & 15 & 18 & 31 & 33 & $9.61^{* * *}$ & $107.45^{* * *}$ \\
\hline Size & 495,052 & 200,215 & $2,692,797$ & 400,606 & $4.36^{* * *}$ & $174.47^{* * *}$ \\
\hline Press Coverage & 11.02 & 11.02 & 14.01 & 14.01 & $6.41^{* * *}$ & $44.8^{* * *}$ \\
\hline FTSE & 0.00 & 0.00 & 0.08 & 0.00 & $7.58^{* * *}$ & $19.14^{* * *}$ \\
\hline
\end{tabular}

Founding Family firms (Model 3), we find a similar pattern. In fact, the interaction term for founding family firms, RATIO $\times$ Founding Family, is negative and highly significant $(\beta=-0.378, \mathrm{p}<0.05)$, while the coefficients of RATIO and RATIO $\times$ Family are no longer significant (RATIO: $\beta=-0.007, \mathrm{p}>0.10$; RATIO $\times$ Family: $\beta=0.107, \mathrm{p}>0.10)$. To sum up, while Founding Family firms are affected by local equity-market conditions, acquired family firms are not, suggesting that the LHB previously reported for Family is only attributable to the subsample of Founding Family firms. H2 is, therefore, supported. In Model (4) the effect of RATIO is further split to distinguish Founder CEO firms. The coefficient of RATIO $\times$ Founder CEO is negative and highly significant (RATIO $\times$ Founder CEO: $\beta=-0.379, \mathrm{p}<0.05)$, supporting H3. On the other hand, RATIO $\times$ Founding Family loses its power $(R A T I O \times$ Founding Family: $\beta=-0.224, p>0.10)$. In all models, relations with the control variables have the expected signs and are all statistically significant (e.g., Model 4, Press Coverage: $\beta=0.137, p<0.01$ ). Overall, after controlling for the variables the literature recognizes as able to affect firm market performance, the multivariate analysis highlights statistically significant effects between RATIO and $M T B V$, and entirely supports our hypotheses. In particular, the investor preference for local equity is entirely driven by founding family firms where the founder serves as CEO: the non orthogonal, nested, definition we use to classify the different types of family firms fits with the aim of our analysis and helps explain why the more nested groups of family firms, with progressively stronger ties to the local community, are able to capture most of the effect we highlight.

The intuition on the economic impact of our findings is presented in Figure 2, which depicts the relation between the local equity-market conditions measured through the variable RATIO (x-axis) and the firm market-to-book value (y-axis) for different types of family firms.

The magnitude of the LHB, measured by the slope of the function that links RATIO and MTBV, increases with each level of firm family-ness, reaching its highest point with Founder CEO firms. Indeed, using the estimates of Model (4) of Table 4, a Founder CEO family firm headquartered in the highest $R A T I O$ region (Lazio, $R A T I O=0.886$ ) would have an estimated marketto-book of about $1.27(\exp (-0.379 \times 0.886+0.58)=1.27)^{7}$, while the same firm located for instance Emilia-Romagna $(R A T I O=0.146)$ has an estimated market-to-book on average the 33 percent higher, and equal to 1.69 $(\exp (-0.379 \times 0.146+0.58)=1.69)$. According to our results, this difference in value $(1.69-1.27=0.42)$ is due to the LHB for a Founder CEO firm. On the other hand, considering the baseline model (Model (1) of Table 3) and irrespective of the family firm type, which is found to significantly drive the results, the market-to-book is about 1.11 for a firm headquartered in Lazio

\footnotetext{
${ }^{7}$ Estimates are obtained as the product of the coefficient of RATIO times the level of RATIO in the considered region plus a constant given by the sum of the products of the statistically significant estimated parameters and the values of the variables for the average firm. The value of the variables is approximated by the variable average value.
} 
Table 4

The effect of RATIO on value in family firms. t-test on clustered standard errors at year and firm level are reported. Model 5 reports Bootstrap with 1000 replications. ${ }^{* * *},{ }^{* *}$, and $*$ indicate statistical significance at the $1 \%, 5 \%$, and $10 \%$ levels.

\begin{tabular}{|c|c|c|c|c|c|}
\hline & \multicolumn{5}{|l|}{ Log(MTBV) } \\
\hline & (1) & $(2)$ & (3) & (4) & (5) \\
\hline RATIO & $-0.113^{* * *}(-3.89)$ & $-0.011(-0.19)$ & $-0.007(-0.12)$ & $-0.010(-0.19)$ & $-0.010(-0.12)$ \\
\hline RATIO $\times$ family & & $-0.178^{* *}(-2.59)$ & $0.107(0.80)$ & $0.105(0.78)$ & $0.105(0.61)$ \\
\hline RATIO $\times$ founding family & & & $-0.378^{* *}(-2.53)$ & $-0.224(-1.22)$ & $-0.224(-1.57)$ \\
\hline RATIO $\times$ founder CEO & & & & $-0.379^{* *}(-2.62)$ & $-0.377^{* * *}(-2.67)$ \\
\hline Family & & $0.052(1.46)$ & $-0.107(-1.82)$ & $-0.108(-1.82)$ & $-0.108(-1.41)$ \\
\hline Founding family & & & $0.215^{* *}(3.13)$ & $0.157^{*}(2.00)$ & $0.157^{* *}(2.05)$ \\
\hline Founder CEO & & & & $0.111^{*}(1.90)$ & $0.111(1.43)$ \\
\hline Own & $0.085^{*}(2.29)$ & $0.086^{* *}(2.36)$ & $0.079 *(2.16)$ & $0.098^{* *}(2.67)$ & $0.098(1.44)$ \\
\hline ROE & $0.255(1.30)$ & $0.262(1.34)$ & $0.253(1.28)$ & $0.249(1.27)$ & $0.249(1.12)$ \\
\hline Log(Age) & $-0.081^{* * *}(-6.81)$ & $-0.084^{* * *}(-6.79)$ & $-0.085^{* * *}(-6.89)$ & $-0.085^{* * *}(-6.72)$ & $-0.085^{* * *}(-5.67)$ \\
\hline $\log ($ Size $)$ & $-0.083^{* * *}(-6.45)$ & $-0.084^{* * *}(-6.28)$ & $-0.086^{* * *}(-6.46)$ & $-0.084^{* * *}(-6.22)$ & $-0.084^{* * *}(-7.45)$ \\
\hline Log( $1+$ Press Coverage $)$ & $0.142^{* * *}(5.67)$ & $0.141^{* * *}(5.56)$ & $0.138^{* * *}(5.43)$ & $0.137^{* * *}(5.29)$ & $0.137^{* * *}(6.98)$ \\
\hline FTSE & $0.431^{* * *}(8.39)$ & $0.426^{* * *}(8.35)$ & $0.435^{* * *}(8.47)$ & $0.425^{* * *}(8.19)$ & $0.425^{* * *}(8.64)$ \\
\hline Constant & $1.110^{* * *}(6.22)$ & $1.098^{* * *}(5.72)$ & $1.272^{* * *}(6.22)$ & $1.252^{* * *}(6.05)$ & $1.252^{* * *}(8.04)$ \\
\hline Dummy market & YES & YES & YES & YES & YES \\
\hline Dummy year & YES & YES & YES & YES & YES \\
\hline Observations & 2951 & 2951 & 2951 & 2951 & 2951 \\
\hline $\mathrm{R}^{2}$-adj & 0.24 & 0.24 & 0.24 & 0.24 & 0.23 \\
\hline
\end{tabular}

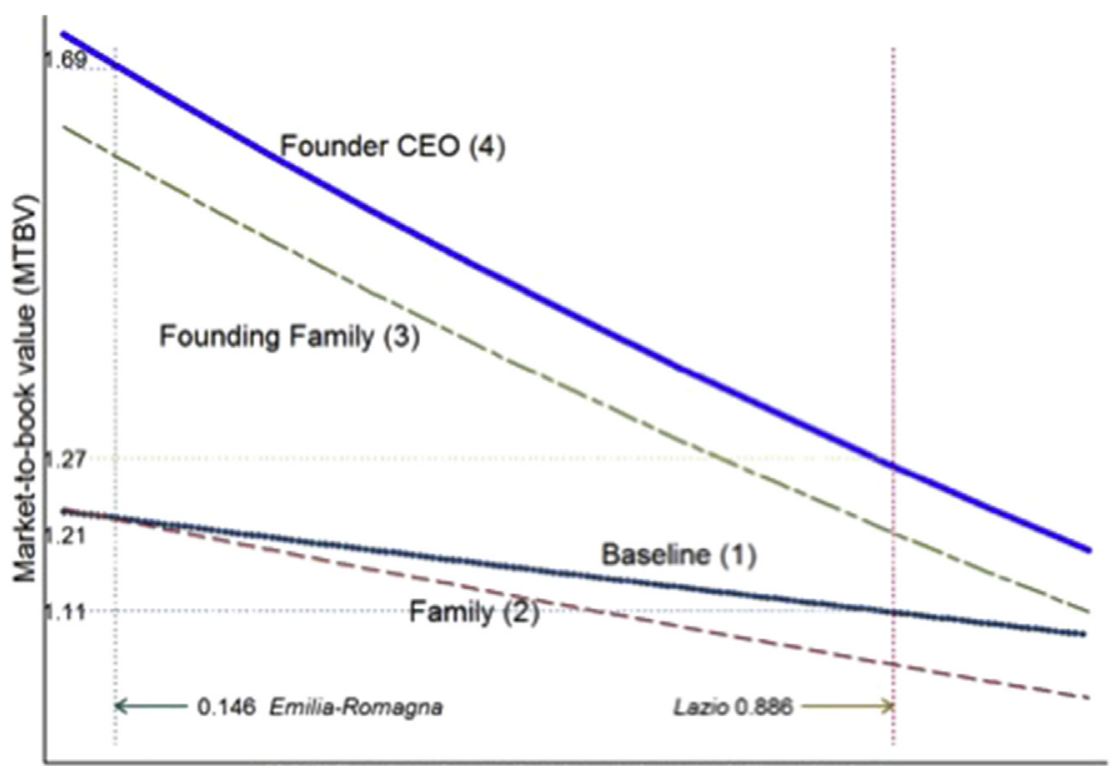

RATIO = local supply / local demand (for stocks)

Figure 2. The Local Home Bias asset pricing implications in family firms. Parameters to draw single functions are from Table 4 (in brackets the model employed).

and about 1.21 if the same firm is headquartered in Emilia-Romagna. In this case, the difference in the market-to-book value ascribed to the LHB is only $0.1(1.21-1.11=0.1)$.

\section{Validity issues}

To test the structural validity of our models, we run additional robustness checks. In particular, in Model (5) of Table 3 we re-run Model (4) of Table 3 via boostrapping, using 1,000 replications (with replacement) of sub-samples of 1,000 observations each. The main findings are unchanged. For example, the coefficient of RATIO $\times$ Founder CEO is negative and highly significant as previously reported $(\beta=-0.377, \mathrm{p}<0.01)$.

Then, we consider that one of the main changes in the Italian corporate governance legal framework occurred in 2004, resulting in an increased degree of autonomy and flexibility achievable through the company by-laws (i.e. 'Vietti's law'). To control for regulatory changes we split our sample in two subsamples of observations before and after 2004, and replicate the analysis of Model (4) in Table 3. Once again, findings (not reported) are unchanged with respect to previous results. 


\title{
Discussion and conclusions
}

\author{
Key findings
}

Understanding the roots of investors' tendency to overinvest in nearby listed (family) firms has received scant attention within the literature. Yet, the implications of the so-called LHB are highly relevant for both firm management and entrepreneurial activity as the LHB affects the corporate market values and the firm's cost of capital (e.g., Hong et al. 2008; Korniotis and Kumar, 2013). In light of the importance of family-controlled firms in the corporate landscape around the world (e.g., Faccio and Lang, 2002), this paper fills this gap by addressing the link between the locally embedded nature of family firms and the LHB.

We find that the particular link a family firm establishes with its hosting community boosts the investor's preference for local stocks. The LHB does not indiscriminately exist in all family firms, but is particularly relevant in founding family firms where the founder serves as CEO. In fact, creating a business instils in the founder a greater identification with the community (e.g., Hollander and Elman, 1988), which, in turn, translates into a greater local involvement both at corporate- and familylevel. Ultimately, the founder enhances corporate actions that maximize familiarity with the founding family firm by local investors, thus favourably shaping their trading pattern. All other things being equal, isolated and locally committed family firms are able to boost feelings of familiarity and capture the local unsatisfied demand for stocks that pushes the firm's stock price up: the isolated founder-managed family firm headquartered in regions with a short supply of local stocks has a value on average about 33 percent higher than the clustered founder-managed family firm located in regions with the presence of several listed firms. Overall, founder-CEO founding family firms exploit the local dedicated clientele and shrink their cost of funding.

\section{Implications for researchers}

Our contribution to the literature takes on several different dimensions. To the best of our knowledge, we are the first to show detailed data on the Register of Shareholders from a family firm. We believe our case-study, with the analysis of a founding family firm ownership structure and shareholder location, provides new and conclusive evidence on the existence of LHB within the Italian family firm setting. In addition, the distinction between local retail and institutional investors sheds light on the underlying mechanism driving the LHB and related effects.

The literature indicates that family firm characteristics are peculiar, compared to other types of businesses, and can be best examined with dedicated studies (e.g., Salvato and Aldrich, 2012). Our results add evidence to these factors, showing the greater ability of family firms to trigger the LHB which in turn affects corporate aspects such as payout policy (e.g., Becker et al., 2011), corporate market value or the firm cost of capital (e.g., Hong et al., 2008; Korniotis and Kumar, 2013). Ultimately, we add to the existing literature by showing a (local) perspective that sheds new light on the prior findings and expands the current understanding of the issue. As an example, Naldi et al. (2013) show family firms with a family CEO perform differently based on their business context. These firms over-perform compared to other family firms in industrial districts where social norms and the informal component of the institutional environment is particularly important; yet, they underperform in stock exchange markets due to higher governance burden or managerial opportunistic behaviors. While our results showing the superior performance of the listed founder-managed family firms may appear to conflict with Naldi et al. (2013), we consider a novel (local) perspective, thus supporting their evidence and highlighting a connection between their diverse results. In fact, we find the listed founder-managed family firms trade at a premium due to a local investor preference generated by the relationships the founder CEO builds through interdependent linkages between the firm and the local stakeholders such as local suppliers and financial institutions. Consistent with Naldi et al. (2013), we expect local bonds to be much stronger in industrial districts even for listed founder-managed family firms. Similarly, the sizable but mixed evidence supporting family firms as best performers (e.g., Anderson and Reeb, 2003; Villalonga and Amit, 2006), could be reinterpreted by considering a local perspective. A large part of the literature highlights that family firms bear a discount factor in their evaluation (among the first, Holderness and Sheenan, 1988), yet our findings show opposite results where family firms, with a founder CEO embedded in the local community, trade at a premium compared to other family and non-family firms. Our results are in line with Villalonga and Amit (2006) showing that family ownership creates value only when the founder serves as the CEO in the family firm or as the Chairman in firms with a hired CEO. In addition, we add a novel perspective of analysis to the prior literature and suggest that only the isolated and locally committed family firms ultimately trade at a premium. The clustered family firms are in fact unable to exploit the dedicated local clientele pushing stock prices up, thus explaining the evidence of negative performance in the literature on family firms.

The lack of results we find for the isolated vs. clustered non-family firms also represents new evidence to the literature that, so far, has not considered the peculiar dynamics of family firms (e.g., Hong et al., 2008). We suggest the lack of results on the local non-family firms is related to a lower commitment that non-family firms have in forming bonds with their local community. This behaviour might be explained by several factors, such as non-family firms placing greater emphasis on business internationalization policies (e.g., Majocchi and Strange, 2012; Gomez-Mejia et al., 2010) or their lower commitment in responding to local institutional pressures (Berrone et al., 2010). We believe the local behaviour of non-family firms is worth investigating and represents a call for future research. 
Several future lines of research emerge. In the first place, we show the spatial dimension of family capitalism can be treated as a multidimensional topic from both a methodological and a theoretical standpoint. Despite a growing number of studies on the effect of firm location on multiple aspects of corporate finance and entrepreneurship (e.g., Carosi, 2016; Chen et al., 2014), no investigation has been published with specific reference to family firms. We fill a gap in the financial literature and highlight that the spatial dimension is even more critical for family owned businesses because of increased local involvement. Yet, we highlight that family firms are not a homogeneous group even in their ability to build ties with the local community or their focus on social, rather than economic, goals. Recent research shows firms with high local ownership have better internal governance (Chhaochharia et al. 2012) and geographically proximate firms have similar financing policies (Gao et al. 2011). Meanwhile, founding family firms epitomize local ownership (Chrisman et al. 1998) and debt-aversion (González et al., 2013). So, the spatial dimension explains corporate governance, leverage, and related performance implications across different types of family firms. In light of multiple aspects of corporate geography, we believe there are several directions for future research.

Finally, recent literature documents that media affects returns (Fang and Peress, 2009) and local media affects local trading (Engelberg and Parsons, 2011). As a firm's current owner can influence local investors especially where there is a stronger link with the territory, the interdependent relationship between family firms and local media - for instance looking at how local media represent local family firms - is a promising field of research. Moving forward, a less stereotyped approach is needed. Using a dynamic framework, the aim should be to investigate the potential of family businesses in affecting the social environment and, in doing so, their practice and performance. To date, it is still unclear whether shrinking the cost of funding is an intended result family firms explicitly seek when engaging with the local community or if it is an accidental, yet welcome, consequence of a behaviour aimed at, for example, enhancing the family's socio-emotional wealth. Understanding the prevalence of economic or non-economic drivers behind family firm actions is not specifically tackled in this study and definitely represents a call for future research.

\section{Implications for policy-makers and practitioners}

Policy increasingly encourages the development and creation of new ventures, especially in the more economically depressed areas of the country, where problems of regional and social inequality are highest. Yet, particularly after the global financial crisis, it is increasingly difficult and expensive to access to new capital in order to expand or establish new business activities (Diamond and Rajan, 2009). In this context, the literature shows that in deprived communities, family firms focus on both economic and social goals more than other types of businesses (Birley et al. 1999). In contrast with conventional approaches, our results suggest the representation of family firms is more intricate than the "local fairy godmother", as corporate and family member actions within the local community attract local investor funding which ultimately shrinks the firm's cost of capital. Within this framework, the family's local involvement could have opportunistic traits and the founder management appears to be the watershed. In some ways, the apparently clear distinction between financial and non-financial factors in family firm's owner utility functions is indeed ambiguous. In fact, the firm's contributions to the local community or even its philanthropy translate into a pecuniary benefit due to the decrease in the cost of funding because of the local dedicated clientele exploitation. For example, the recent acquisition by Buffet's Berkshire Hathaway of the Omaha WorldHerald Co., Warren Buffet's hometown newspaper, could be driven by economic reasons rather than by an attempt to support Buffet's local community. In other words, philanthropy may have more than merely social effects, as it creates value for the firm through an improvement of the business perception. Thus, when defining local development strategies or policies supporting philanthropy activities, policymakers need to consider the non-trivial implications of investor preference for local family firms stocks. A similar conclusion holds for family firms activating a corporate social responsibility policy.

Finally, in light of these findings, as local shareholders can have a signalling effect for non-local shareholders and local shareholders tend to be attracted by founder-managed founding family firms, the latter could eventually be considered a preferable vehicle for pushing the economic development of the more depressed areas in a country.

\section{Acknowledgements}

Thanks to two anonymous referees, Gianvito Lanzolla, Gianni Lorenzoni, Simone Ferriani, Antonio Majocchi, Jennifer Monroe, and Carlo Salvato as well as participants at Cass Finance Research Seminars (April 2010) and The Multinational Finance Society Annual Conference (July 2010) for comments and suggestions. The views expressed herein are those of the authors and we alone bear responsibility for any mistakes and inaccuracies.

This research did not receive any specific grant from funding agencies in the public, commercial, or not-for-profit sectors.

\section{References}

Ackert, L.F., Church, B.K., Tompkins, J., Zhang, P., 2005. What's in a name? An experimental examination of investment behavior. Review of Finance 9, $281-304$.

Aganin, A., Volpin, P., 2005. The history of corporate ownership in Italy. In: Morck, R.K. (Ed.), A History of Corporate Governance around the World: Family Business Groups to Professional Managers. University of Chicago Press, pp. 325-366.

Anderson, R.C., Reeb, D.M., 2003. Founding-family ownership and firm performance: Evidence from the S\&P 500. Journal of Finance 58, 1301-1328. 
Arregle, J.-L., Hitt, M.A., Sirmon, D.G., Very, P., 2007. The development of organizational social capital: Attributes of family firms. Journal of Management Studies 44, 73-95.

Astrachan, J.H., 1988. Family firm and community culture. Family Business Review 1, 165-189.

Athanassiou, N., Crittenden, W.F., Kelly, L.M., Marquez, P., 2002. Founder centrality effects on the Mexican family firm's top management group: Firm culture, strategic vision and goals, and firm performance. Journal of World Business 37, 139-150.

Baik, B., Kang, J.-K., Kim, J.-M., 2010. Local institutional investors, information asymmetries, and equity returns. Journal of Financial Economics 97, 81-106.

Baker, W., 1990. Market networks and corporate behavior. American Journal of Sociology 96, 589-625.

Barontini, R., Caprio, L., 2006. The effect of family control on firm value and performance: Evidence from continental Europe. European Financial Management 12, 689-723.

Baschieri, G., Carosi, A., Mengoli, S., 2015. Local IPOs, local delistings, and the firm location premium. Journal of Banking \& Finance 53, 67-83.

Becker, B., Ivković, Z., Weisbenner, S., 2011. Local dividend clienteles. Journal of Finance 66, 655-683.

Berghoff, H., 2001. Marketing diversity: The making of a global consumer product - Hohner's Harmonicas, 1857-1930. Enterprise \& Society 2, 338-372.

Berrone, P., Cruz, C., Gomez-Mejia, L.R., 2012. Socioemotional wealth in family firms: Theoretical dimensions, assessment approaches and agenda for future research. Family Business Review 25, 258-279.

Berrone, P., Cruz, C., Gomez-Mejia, L.R., Larraza-Kintana, M., 2010. Socioemotional wealth and corporate responses to institutional pressures: Do familycontrolled firms pollute less? Administrative Science Quarterly 55, 82-113.

Bigelli, M., Mengoli, S., 2011. Self-Expropriation versus Self-Interest in Dual-Class Voting: The Pirelli Case Study. Financial Management 40, 677-699.

Birley, S., Ng, D., Godfrey, A., 1999. The family and the business. Long Range Planning 32, 598-608.

Block, J., 2010. Family management, family ownership, and downsizing: Evidence from S\&P 500 firms. Family Business Review 23, 109-130.

Bodnaruk, A., 2009. Proximity always matters: Local bias when the set of local companies changes. Review of Finance $13,629-656$.

Cao, H.H., Han, B., Hirshleifer, D., Zhang, H.H., 2011. Fear of the unknown: Familiarity and economic decisions. Review of Finance 15, $173-206$.

Caprio, L., Croci, E., Del Giudice, A., 2011. Ownership structure, family control, and acquisition decisions. Journal of Corporate Finance 17, $1636-1657$.

Carosi, A., 2016. Do local causations matter? The effect of firm location on the relations of ROE, R\&D, and firm SIZE with MARKET-TO-BOOK. Journal of Corporate Finance 41, 388-409.

Cennamo, C., Berrone, P., Cruz, C., Gomez-Mejia, L.R., 2012. Socioemotional wealth and proactive stakeholder engagement: Why family-controlled firms care more about their stakeholders. Entrepreneurship Theory and Practice 36, 1153-1173.

Chen, Y., Podolski, E.J., Rhee, S.G., Veeraraghavan, M., 2014. Local gambling preferences and corporate innovative success. Journal of Financial and Quantitative Analysis 49, 77-106.

Chhaochharia, V., Kumar, A., Niessen-Ruenzi, A., 2012. Local investors and corporate governance. Journal of Accounting and Economics 54, $42-67$.

Chrisman, J.J., Chua, J.H., Sharma, P., 1998. Important attributes of successors in family businesses: An exploratory study. Family Business Review 11, 19-34. Chua, J.H., Chrisman, J.J., Sharma, P., 1999. Defining the family business by behavior. Entrepreneurship Theory and Practice 23, $19-39$.

Coval, J.D., Moskowitz, T.J., 1999. Home bias at home: Local equity preference in domestic portfolios. Journal of Finance 54, $2045-2073$.

Coval, J.D., Moskowitz, T.J., 2001. The geography of investment: Informed trading and asset prices. Journal of Political Economy $109,811-841$.

Diamond, D.W., Rajan, R.G., 2009. The credit crisis: Conjectures about causes and remedies. American Economic Review 99, 606-610.

Døskeland, T.M., Hvide, H.K., 2011. Do individual investors have asymmetric information based on work experience? Journal of Finance 66, 1011-1041.

Dyer, W.G., Whetten, D.A., 2006. Family firms and social responsibility. Preliminary evidence from the S\&P 500. Entrepreneurship Theory and Practice 30, $785-802$.

Engelberg, J.E., Parsons, C.A., 2011. The causal impact of media in financial markets. Journal of Finance 66, 67-97.

Faccio, M., Lang, L.H., 2002. The ultimate ownership of Western European corporations. Journal of Financial Economics 65, $365-395$.

Fahlenbrach, R., 2009. Founder-CEOs, investment decisions, and stock market performance. Journal of Financial and Quantitative Analysis 44, 439-466.

Fang, L., Peress, J., 2009. Media coverage and the cross-section of stock returns. Journal of Finance 64, $2023-2052$.

Flavin, T.J., 2004. The effect of the Euro on country versus industry portfolio diversification. Journal of International Money and Finance 23, $1137-1158$.

Frieder, L., Subrahmanyam, A., 2005. Brand perceptions and the market for common stock. Journal of Financial and Quantitative Analysis 40, 57-85.

Gao, W., Ng, L., Wang, Q., 2011. Does corporate headquarters location matter for firm capital structure? Financial Management 40, $113-138$.

Gersick, K.E., 2004. National Center for Family Philanthropy (U.S.). Generations of Giving : Leadership and Continuity in Family Foundations. Lexington Books, Lanham.

Gomez-Mejia, L.R., Cruz, C., Berrone, P., De Castro, J., 2011. The bind that ties: Socioemotional wealth preservation in family firms. Academy of Management Annals 5, 653-707.

Gómez-Mejía, L.R., Haynes, K.T., Núñez-Nickel, M., Jacobson, K.J.L., Moyano-Fuentes, J., 2007. Socioemotional wealth and business risks in family-controlled firms: Evidence from Spanish olive oil mills. Administrative Science Quarterly 52, 106-137.

Gomez-Mejia, L.R., Makri, M., Larraza Kintana, M., 2010. Diversification decisions in family-controlled firms. Journal of Management Studies 47, $223-252$.

González, M., Guzmán, A., Pombo, C., Trujillo, M.-A., 2013. Family firms and debt: Risk aversion versus risk of losing control. Journal of Business Research 66, $2308-2320$.

Graafland, J.J., 2002. Corporate social responsibility and family business. In: Research Forum Proceedings of the Family Business Network. Helsinki, Finland. Grinblatt, M., Keloharju, M., 2001. How distance, language, and culture influence stockholdings and trades. Journal of Finance 56, $1053-1073$.

Guiso, L., Sapienza, P., Zingales, L., 2004. Does local financial development matter? Quarterly Journal of Economics 119, $929-969$.

Harris, L.C., Ogbonna, E., 1999. The strategic legacy of company founders. Long Range Planning 32, 333 -343.

Hau, H., 2001. Location matters: An examination of trading profits. Journal of Finance 50, 1959-1983.

Henriques, I., Sadorsky, P., 1996. The determinants of an environmentally responsive firm: An empirical approach. Journal of Environmental Economics and Management 30, 381-395.

Holderness, C.G., Sheenan, D.P., 1988. The role of majority shareholders in publicly held corporations. An exploratory analysis. Journal of Financial Economics 20, 317-346.

Hollander, B.S., Elman, N.S., 1988. Family-owned businesses: An emerging field of inquiry. Family Business Review 1, $145-164$.

Hong, H., Kubik, J.D., Stein, J.C., 2008. The only game in town: Stock-price consequences of local bias. Journal of Financial Economics 90, $20-37$.

Huberman, G., 2001. Familiarity breeds investment. Review of Financial Studies 14, 659-680.

Ivković, Z., Weisbenner, S., 2005. Local does as local is: Information content of the geography of individual investors' common stock investments. Journal of Finance 60, 267-306.

Kahn, J.A., Henderson, D.A., 1992. Location preferences of family firms: Strategic decision making or "Home Sweet Home"? Family Business Review 5, $271-282$. Kang, J.-K., Kim, J.-M., 2008. The geography of block acquisitions. Journal of Finance 63, 2817-2858.

Karlsson, A., Nordén, L., 2007. Home sweet home: Home bias and international diversification among individual investors. Journal of Banking \& Finance 31, $317-333$.

Keloharju, M., Knüpfer, S., Linnainmaa, J., 2012. Do investors buy what they know? Product market choices and investment decisions. Review of Financial Studies 25, 2921-2958.

Khanna, T., Rivkin, J.W., 2001. Estimating the performance effects of business groups in emerging markets. Strategic Management Journal 22, 45-74.

Korniotis, G.M., Kumar, A., 2013. State-level business cycles and local return predictability. Journal of Finance 68, $1037-1096$.

Kumar, A., 2009. Hard-to-value stocks, behavioral biases, and informed trading. Journal of Financial and Quantitative Analysis 44, $1375-1401$.

Lansberg, I., 1999. Succeeding Generations Realizing the Dream of Families in Business. Harvard Business School Press, Boston.

Majocchi, A., Strange, R., 2012. International diversification. Management International Review 52, 879-900.

Massa, M., Simonov, A., 2006. Hedging, familiarity and portfolio choice. Review of Financial Studies 19, 633-685. 
Mengoli, S., Pazzaglia, F., Sapienza, E., 2009. Effect of governance reforms on corporate ownership in Italy: Is it still pizza, spaghetti, and mandolino? Corporate Governance 17 (5), 629-645.

Miller, D., Le Breton-Miller, I., 2005. Management insights from great and struggling family businesses. Long Range Planning 38, 517-530.

Miller, D., Le Breton-Miller, I., Lester, R.H., Cannella, A.A., 2007. Are family firms really superior performers? Journal of Corporate Finance 13, 829-858.

Minichilli, A., Corbetta, G., MacMillan, I., 2010. Top management teams in family controlled companies: "Familiness," "faultliness," and their impact on financial performance. Journal of Management Studies 47, 205-222.

Naldi, L., Cennamo, C., Corbetta, G., Gomez-Mejia, L., 2013. Preserving socioemotional wealth in family firms: Asset or liability? The moderating role of business context. Entrepreneurship Theory and Practice 37, 1341-1360.

Oba, B., Semerciöz, F., 2005. Antecedents of trust in industrial districts: An empirical analysis of inter-firm relations in a Turkish industrial district. Entrepreneurship \& Regional Development 17, 163-182.

Pazzaglia, F., Mengoli, S., Sapienza, E., 2013. Earnings quality in acquired and nonacquired family firms: a socioemotional wealth perspective. Family Business Review 26, 374-386.

Post, J.E., 1993. The greening of the Boston Park Plaza Hotel. Family Business Review 6, 131-148.

Petersen, M.A., 2009. Estimating standard errors in finance panel data sets: Comparing approaches. Review of Financial Studies 22, 435-480.

Raines, S.S., 2002. Implementing ISO 14001: An international survey assessing the benefits of certification. Corporate Environmental Strategy 9, 418-426.

Salvato, C., Aldrich, H.E., 2012. “That's Interesting!” in family business research. Family Business Review 25, $125-135$.

Schulze, W.S., Lubatkin, M.H., Dino, R.N., 2003. Toward a theory of agency and altruism in family firms. Journal of Business Venturing 18, 473-490.

Seasholes, M.S., Zhu, N., 2010. Individual investors and local bias. Journal of Finance 65, 1987-2010.

Teo, M., 2009. The geography of hedge funds. Review of Financial Studies 22, 3531-3561.

Tagiuri, R., Davis, J., 1992. On the goals of successful family businesses. Family Business Review 5, 43-62.

Uhlaner, L.M., 2006. Business family as a team: Underlying force for sustained competitive advantage.” In: Poutziouris, P.Z., Smyrnios, K.X., Klein, S.B. (Eds.), Handbook of Research on Family Business. Edward Elgar, Cheltenham, UK, pp. 125-144.

Villalonga, B., Amit, R., 2006. How do family ownership, control and management affect firm value? Journal of Financial Economics 80 , $385-417$.

Villalonga, B., Amit, R., 2009. How are U.S. family firms controlled? Review of Financial Studies 22, $3047-3091$.

Westley, F., Vredenburg, H., 1991. Strategic bridging: The collaboration between environmentalists and business in the marketing of green products. Journal of Applied Behavioral Science 27, 65-90.

\section{Biographies}

Giulia Baschieri is Assistant Professor of Corporate Finance at the University of Venice. She obtained a Master Degree in Financial Markets and Institutions and a Ph.D. in Financial Markets and Intermediaries at the University of Bologna. She has been exchange Ph.D. in Finance at Cass Business School - City University London, and Adjunct Professor in Corporate Finance at the University of Bologna. Her research interests refer to asset-pricing dynamics tied to corporate geographic location and family firms. Email: giulia.baschieri@unive.it

Andrea Carosi is Assistant Professor of Corporate Finance at the University of Sassari. He obtained a Master Degree in Political Economy at the University of Bologna and Ph.D. in Finance at the Catholic University of Milan. He has been exchange Ph.D at Krannert School of Business, Purdue University, visiting scholar at Westminster Business School, Westminster University, and post-doc research fellow at University of Bologna. Andrea Carosi is an established teacher of executive/master programmes and he is currently Adjunct Professor at the University of Bologna. His current research interests cover corporate governance, asset pricing and asset allocation. Email: acarosi@uniss.it

Stefano Mengoli is Associate Professor of Corporate Finance at the University of Bologna, Italy. His areas of research interest are corporate finance, empirical asset pricing, and corporate governance. His research appears in journals such as Journal of Banking and Finance, Family Business Review, Financial Management, Corporate Governance: An International Review, International Review of Financial Analysis, and Journal of Management and Governance. He has a PhD in Financial Markets from the University of Siena, Italy. He has also been a visiting scholar/PhD student at the London School of Economics and City University Business School. Email: stefano.mengoli@unibo.it 